\title{
PENERAPAN MODEL KONSTRUKSI NILAI KESUNDAAN MELALUI DILEMA MORAL PADA MAHASISWA PROGRAM STUDI PGMI STAI TASIKMALAYA
}

\author{
Bekti Bernardi, Kama Abdul Hakam, Cece Rakhmat, Aceng Kosasih \\ Universitas Pendidikan Indonesia, Bandung, Indonesia \\ Correspondence Email: bektibeza@gmail.com
}

\begin{abstract}
Abstrak
Penelitian ini akan mengungkap dan membuat model pembelajaran konstruksi nilai kesundaan dirancang dan dikembangkan melalui tahap analisis masalah dan kebutuhan pengguna, perancangan dan pengembangan, validasi ahli dan revisi, serta tahap uji coba berulang. Model pembelajaran secara konseptual terdiri dari komponen-komponen yang saling berkaitan dan saling mendukung antara satu sama lain. Komponen-komponen tersebut terdiri dari sintaks, sistem sosial, prinsip reaksi, dan dukungan sistem. Sintaks (Sytntax) model pembelajaran ini dibagi ke dalam tiga tahap kegiatan, yaitu pendahuluan, kegiatan inti, dan kegiatan penutup. Pendekatan penelitian ini menggunakan metode research and developent (penelitian dan pengembangan). Subjek penelitian ini adalah mahasiswa PGMI STAI Tasikmalaya. Hasil temuan terkait permasalahan pembelajaran nilai kesundaan yang dilakukan praktisi dapat berimplikasi pada peninjauan perbaikan kebijakan terkait pembelajaran nilai kesundaan, baik pada lembaga perguruan tinggi maupun pada lembaga pendidikan lainnya. Uji coba model pembelajaran konstruksi nilai berimplikasi pada kemampuan dosen dalam melaksanakan pembelajaran. Langkahlangkah model pembelajaran konstruksi nilai kesundaan dapat membantu dosen dalam meningkatkan kematangan moral mahasiswa.
\end{abstract}

Kata Kunci:

Model, Konstruksi, Pembelajaran, Sunda

\begin{abstract}
This research will reveal and create a learning model of delay value construction designed and developed through the problem analysis stage and user needs, design and development, expert validation and revision, as well as a repeated trial phase. The conceptual learning model consists of components that are interrelated and mutually support one another. These components consist of syntax, social systems, reaction principles, and support systems. The syntax (Sytntax) of this learning model is divided into three stages of activity, namely introduction, core activity, and closing activity. This research approach uses research and developent methods (research and development). The subjects of this study were students of PGMI STAI Tasikmalaya. The findings related to the problem of learning the value of delay carried out by practitioners can have implications for reviewing policy improvements related to learning the value of delay, both in tertiary institutions and in other educational institutions. Testing the value construction learning model has implications for the ability of lecturers to carry out learning. The steps of the delay value construction learning model can help the lecturer in increasing the moral maturity of students.
\end{abstract}

\section{Keywords:}

Model, Construction, Learning, Sundanese

\section{A. INTRODUCTION}

Konstruksi atas nilai suatu budaya beririsan dengan 'rekayasa budaya' sebagai upaya merevitalisasi peran budaya lokal dan pengusungnya. Timmerman (2018) mengartikan rekayasa budaya sebagai aspek riset yang dikembangkan dari paradigma 'kajian budaya' (culture studies), semangat dasarnya adalah melakukan identifikasi, artikulasi dan advokasi atas nilai-nilai seni-budaya. Hal itu menurutnya, dilakukan untuk proses emansipasi dan revitalisasi akar budaya 
lokal, sehingga memungkinkan pendukung budaya lokal mampu menggunakan modal budaya (cultural capital) mereka untuk tujuan kolektif dalam mengembangkan warisan kebudayaan secara adaptif dan fungsional, tanpa kehilangan identitas atas nilai-nilai residual kebudayaannya.

Pendidikan nilai moral menyertakan, pertama: pendekatan transmisi (ketika nilai moral baik itu memang harus dibiasakan, diberikan, atau dipindahkan dari satu generasi ke generasi berikutnya), dan pendekatan konstruksi (ketika nilai moral baik itu pada saatnya memerlukan pijakan pemahaman). Pada konteks kehidupan masyarakat Sunda, perlu lebih banyak diadakan penelitian mengenai: kenalkah orang Sunda pada etika Sunda?, apakah nilai moral Sunda diimplementasikan pada kehidupan kampus atau dunia persekolahan oleh orang Sunda?, bagaimana mengkonstruksikan nilai moral Sunda melalui pendekatan etnopedagogi?, dan sederet pertanyaan lainnya dalam gugusan permasalahan konstruksi nilai moral Sunda.

Dalam kosa kata "nilai kesundaan", secara implisit terkandung subjektivisme nilai. Artinya, orang Sunda yang dalam hidupnya berusaha menghayati jatidiri kesundaannya, menilai bahwa dalam dokumen atau artefak budaya Sunda (fisik dan non fisik) terkandung nilai yang kaya dan berharga, antara lain nilai moral atau etik, yang mendorong orang Sunda untuk dapat mengembangkan laku hidup berdasarkan nilai dan konsepsi adab Sunda.

Ada beberapa usaha konstruksi nilai moral yang perlu dilakukan diantaranya (1) menjadikan gugusan langkah konstruksi atas nilai moral menjadi bagian dari sumber kesejahteraan masyarakat, (2) perlunya upaya konstruksi nilai moral yang menekankan pada pembiasaan tindakan moral, pembinaan nilai moral, dan pemberdayaan nilai moral (pribadi) tersebut dalam konteks kehidupan kewargaan (nilai moral publik/kolektif), (3) perlunya mendorong terbentuknya masyarakat budaya (cultural citizenship) melalui literasi budaya.

Komponen esensial kepribadian manusia adalah nilai (values) dan kebajikan (virtues). Nilai dan kebajikan ini harus menjadi dasar pengembangan kehidupan manusia yang memiliki peradaban kebaikan dan kebahagiaan secara individual maupun sosial. Gagasan etnopedagogi sendiri adalah praktik pendidikan berbasis kearifan lokal dalam berbagai ranah serta menekankan pengetahuan atau kearifan lokal sebagai sumber inovasi dan keterampilan yang dapat diberdayakan demi kesejahteraan masyarakat. Kearifan lokal tersebut terkait dengan bagaimana pengetahuan dihasilkan, disimpan, diterapkan, dikelola, dan diwariskan (Alwasilah dkk, 2009). Secara ringkas etnopedagogi dapat dikatakan sebagai pendekatan, basis sekaligus suatu proses pembudayaan yang dilakukan melalui rencana dan serangkaian pembelajaran. Bertitik tolak dari pemahaman bahwa wujud kebudayaan itu meliputi gagasan atau ide, aktivitas dan artefak (dalam bentuk fisik dan non fisik), maka proses pembudayaan dalam studi etnopedagogi meliputi makna pembelajaran mengenai gagasan, aktivitas dan ragam bentuk artefak budaya.

Model pembelajaran berbasis etnopedagogi yang dikembangkan tersebut dimaksudkan agar dapat dimanfaatkan sebagai upaya untuk (1) meningkatkan kualitas praktik pembelajaran serta peningkatan 
kapasitas kompetensi dosen dan mahasiswa, khususnya di lingkungan perguruan tinggi keagamaan Islam, (2) sebagai rujukan model pembelajaran berbasis etnopedagogi yang bersumber dari upaya konstruksi nilai moral yang terkandung dalam budaya Sunda, (3) membantu program pemerintah nasional maupun daerah setempat dalam melaksanakan upaya pemaknaan dan pendayagunaan (konstruksi) atas nilai-nilai moral yang terkandung dalam artefak budaya masyarakat lokal yang sarat dengan kearifan dan keunggulan lokal khususnya yang ada di Jawa Barat, (4) umpan balik bagi pengembangan keilmuan di perguruan/pendidikan tinggi dalam memperbaiki, meningkatkan dan mengembangkan inovasi pembelajaran.

\section{B. METHOD}

Pendekatan penelitian ini menggunakan metode research and developent (penelitian dan pengembangan). Konsep dan prinsip penelitian dan pengembangan secara jelas ditulis oleh Borg dan Gall (1989), sebagai berikut: "education research and development is a process used to develop and validate education product". Penelitian dan pengembangan adalah suatu proses yang digunakan untuk mengembangkan dan memvalidasi produk-produk pendidikan.

Siklus penelitian dan pengembangan meliputi studi hasil-hasil penelitian untuk mengembangkan produk, melakukan uji lapangan, dan terakhir memperbaiki produk tersebut berdasarkan temuan lapangan. Hal ini sesuai pendapat Sugiyono (2007) yang mengemukakan bahwa "untuk dapat menghasilkan produk tertentu digunakan penelitian yang bersifat analisa kebutuhan dan untuk menguji keefektifan produk tersebut supaya dapat berfungsi di masyarakat luas, maka diperlukan penelitian untuk menguji keefektifan produk tersebut".

Berdasarkan langkah-langkah yang dilaksanakan, maka penelitian dan pengembangan bersifat longitudinal, yaitu selalu mendasarkan pada kegiatan secara berulang-ulang. Menurut Borg and Gall (1979), ada 10 langkah dalam proses penelitian pengembangan. Langkah-langkah tersebut dapat diuraikan sebagai berikut :

1. Research and information collecting (penelitian dan pengumpulan informasi), pada tahap ini meliputi: kajian literatur, melakukan observasi lapangan, membuat persiapan laporan. Kajian literatur dilakukan untuk menentukan wilayah pengetahuan mana penelitian yang dilakukan, sehingga dapat menunjang pengembangan keterampilan pemilihan dan penyusunan bahan ajar/satuan acara perkuliahan.

2. Planning (perencanaan), meliputi kegiatan: pendefinisian jenis keterampilan, menentukan tujuantujuan yang diharapkan, menetapkan langkah-langkah pembelajaran, dan uji kelaikan dalam skala kecil. Kegiatan perencanaan diawali dengan pendefinisian keterampilanketerampilan yang diharapkan, menyesuaikan tujuan-tujuan yang sesuai dengan keterampilanketerampilan tersebut, kemudian menentukan urutan pembelajaran dan diakhiri dengan melakukan uji kelaikan dalam skala kecil.

3. Develop preliminary form of product (mengembangkan produk pendahuluan) berupa kegiatan penyusunan draft buku ajar pedoman pemilihan dan 
penyusunan bahan ajar atau satuan acara perkuliahan berbasis etnopedagogi yang dapat mengkonstruksi nilai (moral) kesundaan.

4. Preliminary field testing (melakukan pengujian pendahuluan), yang dilakukan pada satu kelas perkuliahan mahasiswa program strata (1) di lingkungan Sekolah Tinggi Agama Islam Tasikmalaya. Data yang diperoleh melalui observasi, angket dan tes, kemudian dianalisis.

5. Main product revision (melakukan revisi produk utama), sesuai saran dan temuan dari lapangan maka dilakukan perbaikan terhadap hasil pengujian pendahuluan, dalam hal ini mengenai pengembangan keterampilan pemilihan dan penyusunan bahan ajar atau satuan acara perkuliahan berbasis etnopedagogi yang dapat mengkonstruksi nilai kesundaan, sehingga darinya dapat disusun revisi produk.

6. Main field testing (melakukan pengujian lapangan), dilakukan uji coba draft ke-2 dengan melibatkan dosen pakar yang memiliki kompetensi terhadap pengembangan bahan ajar serta bersedia mengkaji dan memberikan saran perbaikan pada peneliti.

7. Operasional product revision (merevisi produk operasional), dilakukan perbaikan sesuai saran dan hasil-hasil pengujian lapangan.

8. Operasional field testing (melakukan pengujian operasional): uji coba draft ke-3 buku ajar dengan melibatkan beberapa kelas perkuliahan untuk kemudian dianalisis.

9. Final product revision (merevisi produk akhir): dilakukan perbaikan berdasarkan pada hasil pengujian operasional dan uji coba draft ke-3 buku ajar.

10. Dessimination and distribution (desiminasi dan distribusi), pada langkah ini dilakukan monitoring sebagai kontrol terhadap kualitas program.

Dari sepuluh langkah tersebut di atas, dapat disederhanakan menjadi tiga tahapan dasar, yakni "secara garis besar langkah penelitian dan pengembangan yang dikembangkan oleh Sukmadinata dan kawan-kawan terdiri atas tiga tahap, yaitu: 1) studi pendahuluan; 2) pengembangan model; dan 3) uji model" (Sukmadinata, 2006).

\section{RESULTS}

\section{MODEL KONSEPTUAL PENELITIAN Draft Awal Model Dilema Moral}

Pengembangan model pembelajaran untuk meningkatkan kematangan pertimbangan moral mahasiswa digunakan model diskusi dilema moral. Model pembelajaran ini dimulai dengan penyusunan rencana pembelajaran, implementasi pembelajaran dan evaluasi. Berdasarkan prosedur penelitian, sebagaimana hasil pra survei, tentang pola pembelajaran yang selama ini dilaksanakan, sebagai langkah awal perencanaan pengembangan dilakukan kegiatan diskusi dengan para dosen yang menjadi subjek penelitian. Diskusi yang dimaksudkan untuk menyamakan persepsi tentang hakikat dan tujuan pembelajaran untuk mengembangkan penalaran moral mahasiswa. Berdasarkan rumusan masalah penelitian, maka pembahasan mengkaji-ulang terhadap tiga bentuk desain, yakni perencanaan pembelajaran, pelaksanaan (implementasi) pembelajaran, dan evaluasi pembelajaran. 
Dari pembahasan dan kajian ini kemudian menghasilkan sebuah model awal (draft) pengembangan model pembelajaran diskusi dilemma moral. Draft awal pengembangan model pembelajaran ini menjadi model pembelajaran dikembangkan lebih lanjut melalui proses uji-coba terbatas dan uji-coba luas sehingga menghasilkan model final hipotetik yang siap divalidasi.

Model yang dikembangkan terdiri dari tiga komponen kegiatan yaitu rencana pembelajaran, pelaksanaan pembelajaran, dan evaluasi pembelajaran. Pengembangan model pembelajaran ini disesuaikan dengan hal-hal sebagai berikut, yaitu : kondisi pembelajaran selama ini sebagaimana yang tergambar pada hasil survey awal, teori-teori pembelajaran yang mendukung dengan orientasi model pembelajaran ini yang diambil dari kajian-kajian literatur, dengan mempertimbangkan karakteristik mahasiswa, kemampuan dosen, karakteristik materi dan tujuan pembelajaran sehingga diharapkan dapat mengembangkan kemampuan penalaran moral mahasiswa.

Model pembelajaran secara konseptual terdiri dari komponenkomponen yang saling berkaitan dan saling mendukung antara satu sama lain. Komponen-komponen tersebut adalah sintaks, sistem sosial, prinsip reaksi, dan dukungan sistem (Joyce, 1992: 14).

Sintaks adalah tahapan-tahapan kegiatan pembelajaran yang harus dilalui; sistem sosial merupakan peran dosen dan siswa yang harus ditunjukkan dalam pembelajaran; prinsip reaksi berarti bagaimana cara dosen memberikan peluang dan kesempatan kepada siswa untuk belajar dan merespon terhadap yang dilakukan siswa; sistem dukung (support system) diartikan sebagai persyaratan tambahan untuk berjalannya suatu model pembelajaran yaitu dapat berupa sarana prasarana, dan lingkungan lainnya yang mendukung.

Komponen pada desain awal model perencanaan pembelajaran untuk mengembangkan penalaran moral mahasiswa mengacu pada pola perencanaan yang selama diberlakukan di STAI Tasikmalaya. Komponen rencana pembelajaran pada pengembangan model pembelajaran untuk meningkatkan kematangan pertimbangan moral mahasiswa, terdiri dari beberapa komponen tujuan pembelajaran, materi pokok, kegiatan pembelajaran; sumber, alat dan media, serta penilaian.

a. Tujuan Pembelajaran

Tujuan dari model pembelajaran ini adalah membantu mahasiswa secara bertahap (dari satu tahap pada suatu waktu) berkembang hierarki moralnya, dan berarti mengembangkan penalaran moral untuk menghasilkan pertimbangan moral yang lebih baik.

b. Metode pembelajaran

Metode yang digunakan dalam meningkatkan kematangan pertimbangan moral mahasiswa adalah diskusi dilema moral. Diskusi dilema moral merupakan salah satu metode diskusi dalam pendekatan perkembangan moral kognitif sehingga dengan mengajak mahasiswa berdiskusi mengenai kasus berdilema moral diharapkan mahasiswa dapat belajar mempertanggung jawabkan pilihan moralnya. Adisusilo (2012) menyatakan bahwa metode diskusi dilema moral memberikan kebebasan 
kepada mahasiswa untuk berani mengungkapkan nilai yang dimilikinya dimana dalam pengajarannya yang lebih diutamakan bukan pada nilai seperti apa yang dipilih melainkan alasan dalam memilih nilai tersebut.

c. Materi Pembelajaran

Materi pembelajaran merupakan materi pokok beserta uraiannya yang perlu dipelajari mahasiswa. Materi pokok ini diorientasikan untuk memfasilitasi mahasiswa menguasai matakuliah sesuai capaian pembelajaran yang hendak dicapai. Dosen dalam memilih, mengembangkan dan menetapkan materi pokok perlu mempertimbangkan kebutuhan dan perkembangan yang terjadi dimasyarakat, serta minat, kemampuan, karakteristik dan perkembangan kognitif mahasiswa.

d. Kegiatan Pembelajaran

Kegiatan pembelajaran terdiri beberapa langkah, yaitu sebagai berikut:

1. Langah

Pertama:

Menghadapkan mahasiswa dengan satu dilema moral, dapat berupa antara lain lembar cerita, roleplaying, fragmen film, atau klipping koran. Peserta didik harus dapat memahami "masalah pokok" yang dilematis yang dihadapi tokoh utama dalam cerita.

2. Langkah Kedua: Menetapkan posisi sementara. Dosen memberi kesempatan kepada peserta didik untuk menetapkan posisi sementara dirinya dalam dilema moral yang dihadapi, dengan cara menuliskan posisinya.

3. Langkah Ketiga: Mengkaji penalaran/pertimbangan

moral. Mahasiswa dibagi ke dalam kelompok-kelompok kecil untuk mengkaji pertimbangan moralnya (moral reasoning) dalam kelompoknya.

4. Langkah Keempat: Memikirkan secara mendalam setiap posisi individual (reflect on the individual position). Dosen membantu mahasiswa sekali lagi untuk merenungi posisinya dalam dilema moral tersebut.

5. Langkah Kelima, Kegiatan Penutup: Dalam kegiatan penutup, dosen bersama-sama dengan mahasiswa membuat rangkuman/simpulan

pembelajaran, serta melakukan refleksi terhadap kegiatan yang sudah dilaksanakan, memberikan umpan balik terhadap proses dan hasil pembelajaran, dan menyampaikan rencana pembelajaran pada per $\neg$ temuan berikutnya.

e. Sumber, Alat dan Media

Sumber, alat dan media dalam suatu proses pembelajaran, berfungsi membantu mahasiswa agar lebih mudah menerima, memahami, dan menguasai materi pelajaran dalam rangka mencapai tujuan pembelajaran yang telah ditetapkan. Beberapa sumber, alat maupun media yang dapat digunakan dalam proses pembelajaran ini. Alat maupun media tersebut dapat berupa media cetak seperti buku, majalah, koran, maupun media gambar, 
foto, atau media elektronika, ataupun media lain seperti media gambar.

f. Penilaian

Penilaian bertujuan untuk mengetahui seberapa jauh pembelajaran yang diimplementasikan, mencakup semua komponen baik proses maupun hasil, telah berhasil mencapai tujuan yang telah ditetapkan. Oleh karena itu, penilaian pada umumnya terdiri atas penilaian proses dan penilaian hasil. Observasi atau pengamatan dilaksanakan terhadap kegiatan mahasiswa dalam proses pembelajaran, seperti diskusi, mengerjakan tugas, berkomunikasi dan lain-lain. Penilaian hasil dilakukan dengan tes, baik tes objektif maupun essei, adapun untuk mengukur perkembangan penalaran moral (pertimbangan moral) menggunakan skala sikap.

\section{DISCUSSION}

Dari pembahasan dan kajian ini kemudian menghasilkan sebuah model awal (draft) pengembangan model pembelajaran diskusi dilemma moral. Draft awal pengembangan model pembelajaran ini menjadi model pembelajaran dikembangkan lebih lanjut melalui proses uji-coba terbatas dan uji-coba luas sehingga menghasilkan model final hipotetik yang siap divalidasi.

Model pembelajaran diskusi dilema moral yang dikembangkan dalam penelitian ini diorientasikan selain untuk mencapai prestasi akademik, juga didedikasikan untuk mengembangkan penalaran moral mahasiswa. Penalaran moral menjadi penting untuk kematangan pertimbangan moral mereka. Paradigma model pembelajaran ini dikembangkan berdasarkan atas analisis kebutuhan yang diperoleh dari survey awal, kurikulum dan teori-teori pendidikan nilai dan perkembangan penalaran moral sebagai landasan dan sumber pengembangan model.

Model yang dikembangkan terdiri dari tiga komponen kegiatan yaitu rencana pembelajaran, pelaksanaan pembelajaran, dan evaluasi pembelajaran. Pengembangan model pembelajaran ini disesuaikan dengan hal-hal sebagai berikut, yaitu : kondisi pembelajaran selama ini sebagaimana yang tergambar pada hasil survey awal, teori-teori pembelajaran yang mendukung dengan orientasi model pembelajaran ini yang diambil dari kajian-kajian literatur, dengan mempertimbangkan karakteristik mahasiswa, kemampuan dosen, karakteristik materi dan tujuan pembelajaran sehingga diharapkan dapat mengembangkan kemampuan penalaran moral mahasiswa.

Secara teoritis model pembelajaran didasarkan pada teori-teori sebagai berikut, yaitu :

Pertama, Teori Perkembangan Moral (Moral Development Theory). Kohlberg dalam menjelaskan pengertian moral menggunakan istilah-istilah moralreasoning, moral thinking, dan moral judgement sebagai istilah-istilah yang mempunyai pengertian sama dan digunakan secara bergantian. Istilah tersebut dalam bahasa Indonesia sering disebut dengan istilah penalaran moral. Penalaran moral menekankan pada alasan mengapa suatu tindakan dilakukan, daripada sekedar tindakan itu sendiri. Kohlberg tidak memusatkan perhatian pada perilaku moral dan pernyataan-pernyataan orang tentang apakah tindakan tersebut benar atau salah, tapi ia menjadikan penalaran 
moral sebagai bahan kajiannya (Budiningsih, 2004 : 25). Penalaran moral dipandang sebagai suatu struktur pemikiran, bukan isi. Dengan demikian penalaran moral bukanlah tentang apa yang baik dan buruk, tetapi tentang bagaimana seseorang berpikir sampai pada keputusan bahwa sesuatu adalah baik atau buruk (Kohlberg 1981). Penalaran-penalaran moral inilah yang menjadi indikator tingkatan atau tahap kematangan moral. Memperhatikan penalaran mengapa suatu tindakan salah akan memberi penjelasan daripada memperhatikan tindakan seseorang atau bahkan mendengar pernyataannya bahwa sesuatu itu salah (Duska dan Whelan, 1975 dalam Budiningsih, 2004 : 26). Jika penalaran moral dipandang sebagai isi, maka sesuatu dikatakan baik atau buruk akan sangat tergantung pada lingkungan sosial budaya tertentu sehingga sifatnya akan sangat relatif. Tetapi jika penalaran moral dilihat sebagai suatu struktur berpikir, maka akan dapat dikatakan bahwa ada perbedaan penalaran moral antara anak-anak dengan orang dewasa, dan hal ini dapat diidentifikasi melalui tingkat perkembangan moralnya. Purwakania Hasan (2006: 271) menyatakan penalaran moral bukan merupakan penalaran terhadap standar perilaku yang ditentukan oleh konsensus sosial (social-conventional rules), namun lebih merupakan penalaran terhadap standar penerimaan dan penolakan yang berhubungan dengan hak dan kewenangan individu (moral rules).

Kedua, Teori Perkembangan Kognitif Piaget. Sejarah awal "tradisi perkembangan kognitif”, juga disebut "perkembangan struktural", ditemukan dalam karya-karya Jean Piaget (antara tahun 1947-1970) tentang perkembangan kognitif. Pendekatan ini "kognitif" atau "struktural" dalam arti ia menekankan sifat aktif otak anak-anak ketika mereka dengan sadar membangun atau mengelola struktur pikiran dan tindakan. "Premis dasarnya adalah bahwa semua pengetahuan dibangun" (Noddings dalam Nucci, 2008, hlm. 78). Pendekatan ini "perkembangan" dalam arti ia mengidentifikasi serangkaian struktur yang terorganisir yang diubah dalam urutan yang runtut ketika seseorang membangun proses kognitif yang semakin berguna dan kompleks melalui interaksi dengan lingkungannya.

Ketiga, Teori Pendidikan Moral, Emile Durkheim (1961) dalam bukunya: Moral Education yang dialih bahasakan oleh Lukas Ginting, mengemukakan bahwa "ada suatu aspek umum yang terdapat pada semua perilaku yang biasa kita sebut perilaku moral. Semua perilaku semacam itu selalu sesuai dengan kaidah-kaidah yang sudah ada. Bertindak secara moral berarti menaati suatu norma, yang menetapkan perilaku apa yang harus diambil pada suatu saat tertentu, bahkan sebelum kita dituntut untuk bertindak". Bagi Durkheim, "ruang lingkup moralitas adalah ruang lingkup kewajiban. Dan kewajiban adalah perilaku yang telah ditetapkan lebih dahulu". Dalam bukunya ini pula, Durkheim mengemukakan unsur-unsur moralitas yaitu: semangat disiplin dan adanya ikatan pada kelompokkelompok sosial.

Model pembelajaran diskusi dilema moral yang dikembangkan dalam penelitian ini diorientasikan selain untuk mencapai prestasi akademik, juga didedikasikan untuk meningkatkan penalaran moral mahasiswa. Penalaran moral menjadi penting untuk kematangan pertimbangan moral mereka. Paradigma model pembelajaran ini dikembangkan berdasarkan atas 
analisis kebutuhan yang diperoleh dari survei awal, kurikulum STAI Tasikmalaya, dan teori-teori pendidikan nilai dan perkembangan penalaran moral sebagai landasan dan sumber pengembangan model.

Model yang dikembangkan terdiri dari tiga komponen kegiatan yaitu rencana pembelajaran, pelaksanaan pembelajaran, dan evaluasi pembelajaran. Pengembangan model pembelajaran ini disesuaikan dengan hal-hal sebagai berikut, yaitu: kondisi pembelajaran selama ini sebagaimana yang tergambar pada hasil survei awal, teori-teori pembelajaran yang mendukung dengan orientasi model pembelajaran ini yang diambil dari kajian-kajian literatur, dengan mempertimbangkan karakteristik mahasiswa, kemampuan dosen, karakteristik materi dan tujuan pembelajaran sehingga diharapkan dapat meningkatkan kemampuan penalaran moral mahasiswa.

Dalam The Moral Judgment of the Child, Piaget (1932: 78) membedakan dua jenis penalaran moral, masingmasing memiliki pemahaman yang berbeda akan rasa hormat, keadilan, dan hukuman: (1) Moralitas heteronom. Awalnya moralitas didasarkan pada rasa hormat sepihak pada otoritas dan aturan-aturan yang mereka tetapkan. Dari perspektif heteronom, keadilan dipahami sebagai kepatuhan pada otoritas dan kesesuaian dengan aturan suci mereka; konsekuensi dipahami sebagai kerusakan nyata tujuan, yang lebih relevan daripada niat; hukuman penebusan adalah cara yang disukai untuk memperbaiki perilaku. (2) Moralitas otonom. Dari perspektif otonom, moralitas didasarkan pada saling menghormati, ketimbal-balikan, dan kesetaraan di antara rekan-rekan sebaya. Keadilan dipahami sebagai kerjasama dan pertukaran timbal balik yang disepakati bersama. Tujuan dipahami sebagai berhubungan; niat dan konsekuensi dapat ditangkap secara bersamaan; hukuman timbal balik lebih disukai.

Dalam pandangan Piaget, perkembangan moral terkait dengan gerakan dari moralitas heteronom ke moralitas otonom. Namun Piaget, dalam penilaian Nucci dan dan Narvaez (2008: 88) nampak sangat berhati-hati dalam menyebut dua bentuk moralitas ini dengan istilah "tahap" karena (mungkin ia sendiri menyadari) tidak jelas bahwa "gerakan dari moralitas heteronom ke moralitas otonom" itu memenuhi kriteria perkembangan kognitif bagi teori "tahap" (yaitu, urutan yang runtut dari keseluruhan yang tersusun dan terintegrasi secara hirarkis).

Pada intinya, Piaget berpendapat bahwa pendidik dapat mempromosikan perkembangan penalaran moral yang matang dengan berbicara pada anakanak sebagai rekan kerjasama yang sederajat dalam pencarian pengetahuan. Piaget mengkritik Durkheim dengan mengatakan: Pendidik yang berbicara dengan otoritas indoktrinatif, bagaimanapun, akan mempromosikan menguatnya penalaran yang kekanak-kanakan. Ia menganggap pendekatan "perkembangan moral" (darinya) sebagai kutub yang berlawanan dari "pedagogi Durkheim" tentang pendidikan moral.

Demikian pula halnya dengan filsafat moral, Dewantara (2017: 67) mengemukakan bahwa karena sifatnya yang praktis, filsafat moral berbeda dengan logika, metafisika, kosmologi, dan epistemologi, terutama dalam merumuskan tujuannya. Filsafat moral bertujuan untuk mengantar orang 
bertindak baik dan menjadi baik. Tujuan ini dinilai lebih lengkap karena berkaitan dengan keseluruhan hidup manusia, sementara ilmu-ilmu spekulatif yang lain berusaha meneguhkan aktivitas-aktivitas tertentu saja dari manusia. Dalam dekadedekade terakhir ini, filsafat moral - yang juga disebut dengan etika bersinggungan dengan hampir seluruh ilmu dan bidang-bidang kajian yang amat luas.

Ada dua substansi kajian yang paling utama dalam hal ini yakni makna (meaning) dan nilai (value). Nilai adalah dunia makna, ia hadir dan/atau dihadirkan melalui proses pemaknaan. Upaya pemaknaan dapat berarti membangun makna atau mengkonstruksi makna.

Hakam (2016: 78) mengemukakan: "ketika nilai berada dalam pikiran seseorang maka nilai itu menjadi konsep penting dalam hidup, sehingga konsep atau gagasan itu dijadikan standar perilakunya, yaitu standar untuk menampilkan keindahan, keefisienan atau kebermaknaan yang ia dukung dan dipertahankannya, meskipun tidak selalu disadari. Setelah seseorang bersentuhan dan mengetahui sesuatu nilai, nilai tersebut lambat laun akan mempengaruhi keyakinannya sehingga nilai menjadi dasar pemikiran bahkan menjadi dasar tindakannya”. Selanjutnya, dalam kajian Phillip Phenix, nilai-nilai dapat dikembangkan melalui berbagai dunia makna baik dalam symbolic, empirics, ethics, esthetics, synnotetics maupun synoptic.

\section{E. CONCLUSION}

Berdasarkan permasalahan tersebut dirancang dan dikembangkan model pembelajaran konstruksi nilai kesundaan melalui diskusi dilema moral, sehingga menyediakan ruang yang cukup untuk memfasilitasi pendidikan nilai moral dengan berbasis pada khazanah kearifan lokal masyarakat setempat.

Model pembelajaran konstruksi nilai kesundaan dirancang dan dikembangkan melalui tahap analisis masalah dan kebutuhan pengguna, perancangan dan pengembangan, validasi ahli dan revisi, serta tahap uji coba berulang. Model pembelajaran secara konseptual terdiri dari komponen-komponen yang saling berkaitan dan saling mendukung antara satu sama lain. Komponen-komponen tersebut terdiri dari sintaks, sistem sosial, prinsip reaksi, dan dukungan sistem. Sintaks (Sytntax) model pembelajaran ini dibagi ke dalam tiga tahap kegiatan, yaitu pendahuluan, kegiatan inti, dan kegiatan penutup. Kegiatan pembelajaran terdiri dari beberapa langkah, yaitu sebagai berikut:

1. Pendahuluan: Pada tahap ini, kegiatan pembelajaran diorientasikan untuk pengondisian mahasiswa secara moral dan secara intelektual.

2. Kegiatan inti: yang terdiri dari beberapa langkah pembelajaran, yaitu: Langkah Pertama: Menyajikan Dilema Moral. Langkah Kedua: Menyatakan Posisi Moral Sementara. Langkah Ketiga: Mengkaji Penalaran/Menguji Alasan. Langkah Keempat: Menunjukkan Posisi Moral MasingMasing.

3. Penutup: Pada tahap ini selain untuk evaluasi terhadap proses dan hasil belajar, juga dilakukan refleksi bersama antara dosen dan mahasiswa terhadap proses pembelajaran untuk memperbaiki proses pembelajaran selanjutnya. Evaluasi pada hasil belajar yaitu 
untuk mengukur penalaran moral mahasiswa.

Rancangan model pembelajaran konstruksi nilai kesundaan akan melalui proses pengujian dan perbaikan selanjutnya divalidasi dan dijudgment oleh para ahli. Berdasarkan judgment dan validasi para ahli menyatakan bahwa model pembelajaran konstruksi nilai kesundaan dapat digunakan.

\section{Implikasi}

Hasil temuan penlitian terkait permasalahan pembelajaran nilai kesundaan yang dilakukan praktisi dapat berimplikasi pada peninjauan perbaikan kebijakan terkait pembelajaran nilai kesundaan, baik pada lembaga perguruan tinggi maupun pada lembaga pendidikan lainnya. Uji coba model pembelajaran konstruksi nilai berimplikasi pada kemampuan dosen dalam melaksanakan pembelajaran. Langkah-langkah model pembelajaran konstruksi nilai kesundaan dapat membantu dosen dalam meningkatkan kematangan moral mahasiswa.

\section{Ucapan Terima Kasih}

Peneliti mengucapkan terimakasih kepada pihak-pihak terkait diantaranya adalah Kemendikbud yang telah memberikan dana penelitian dan Sekolah-sekolah yang telah memberikan ijin untuk melaksanakan penelitian. Tidak lupa juga seluruh tim yang telah membantu penelitian ini.

\section{Daftar Pustaka}

Adiwikarta, Sudardja. (1988). Sosiologi Pendidikan: analisis sosiologi tentang praksis pendidikan. Bandung: Remaja Rosdakarya.

Alwasilah, A. Chaedar, dkk. (2009). Etnopedagogi Landasan Praktek Pendidikan dan Pendidikan Guru. Bandung: Kiblat.
Ahmadi, Iif Khoiru, dkk. 2012. Mengembangkan Pendidikan Berbasis Kearifan Lokal Dalam KTSP. Jakarta: PT Prestasi Pustakaraya Sutanto, R. (2002). Organic farming towards alternative and sustainable agriculture. Indonesia). Kanisius. Yogyakarta.

Ballantine, J. H., Hammack, F. M., \& Stuber, J. (2017). The sociology of education: A systematic analysis. Routledge.

Barker, Chris. (2000). Cultural Studies, Theory and Practice. London: SAGE Publication.

Barthes, Roland. (2007). Membedah Mitos-Mitos Budaya Massa. Yogyakarta: Jalasutra. --, Roland. (2012). Elemen-Elemen Semiologi. Terjemahan Kahfie Nazaruddin. Yogyakarta: Jalasutra

Bordieu, Pierre. (2010). Arena Produksi Kultural. Terjemahan Yudi Santosa. Bantul: Kreasi Wacana.

Brush, Stephen B., dan Stabinsky, Doreen. (1996). Valuing Local Knowledge: Indigenous People and Intellectual Property Rights. Washington DC: Island Press, (Online), (https:// books.google.co.id/books.

Brooks, J. S., \& Normore, A. H. (2010). Educational leadership and globalization: Literacy for a glocal perspective. Educational Policy, 24(1), 52-82.

Burger, Henry G. (1968). Ethno Pedagogy: A Manual in Cultural Sensitivity with Techniques for Improving Cross Teaching by Fitting Ethnic Patterns. New Mexico: Soouthwestern Cooperative Educational Laboratory INC.

Djahiri, Kosasih. (1996). Menelusuri Dunia Afektif. Bandung: Sekolah 
Pascasarjana Universitas

Pendidikan Indonesia.

Djahiri, Kosasih. (1996). Teknik Pengembangan Program

Pengajaran Pendidikan Nilai Moral. Bandung: Laboratorium Pengajaran PMP IKIP.

Djahiri, Kosasih. (1996). Menelusur Dunia Afektif, Pendidikan Nilai dan Moral. Bandung: Laboratorium Pengajaran PMP IKIP. Djamari (1988)

Dneprov, S. Antonovich \& Krasinikov, V.P. Ethopedagogical Heritage of the Development of Physical Activity in Preservation of The Indigenous Population of West Siberia. 2015 (http://search.proquest.com).

Dietz, S., \& Adger, W. N. (2003). Economic growth, biodiversity loss and conservation effort. Journal of Environmental Management, 68(1), 23-35.

Durkheim, Emile. (1986). Durkheim dan Pengantar Sosiologi Moralitas. Penyunting: Taufik Abdullah \& A.C. Van Der Leeden. Jakarta: Yayasan Obor Indonesia

Ekadjati, Edi S. (1993). Kebudayaan Sunda; suatu pendekatan sejarah. Bandung: Pustaka Jaya.

Frondizi, Risieri. (1963). What is Value. Open Court Publishing Company, yang diterjemahkan oleh Cuk Ananta Wijaya (2001) dengan judul: Pengantar Filsafat Nilai. Yogyakarta: Pustaka Pelajar.

Geriya, I. W. (2004). Nilai Dasar, Nilai Instrumental dan Referensi Hukum dalam Kearifan Lokal Daerah Bali. Majalah Kerta Wicaksana. Denpasar. Fakultas Hukum Universitas Udayana.

Geertz, Cliford. (1973). The Interpretation of Culture. New York: Anchor.
Hakam, Kama Abdul (2008) . Pendidikan Nilai. Bandung: VP (Value Press).

Hakam, Kama Abdul dan Nurdin, Encep Syarief (2016). Metode Internalisasi Nilai-Nilai; untuk memodifikasi perilaku berkarakter. Bandung: CV. Maulana Media Grafika.

Hufad, A. 2007. Ilmu \& Aplikasi Pendidikan. Dalam Bagian 1 Teori Sosiologi Pendidikan (Eds.), (hlm 221-250). Bandung: PT Imperial Bhakti Utama.

Indonesia, P. R., \& Nusantara, W. (1997). Undang Undang No. 23 Tahun 1997 Tentang: Pengelolaan Lingkungan Hidup. Lembar Negara RI Tahun, (3699).

Kartadinata, Sunaryo. (2009). Kata Pengantar dalam Buku: Etnopedagogi (Landasan Praktek Pendidikan dan Pendidikan Guru. Bandung: Kiblat Buku Utama.

Kartadinata, Sunaryo. (2011). Ngawangun Atikan Sunda ku Unsur Budaya. Bandung: dalam Cahara Bumi Siliwangi No. 8 Juni 2011, ISSN 2085-322x.

Khusainov, Z.A., Gaisin., Biktimirov., Valiev., Gilemhanov. (2015). Formation of Ecological Culture in The Aspect of Ethno Pedagogy. Mediterranean Journal of Social Sciences. Vol.6 No.1 Februari 2015 (http://search.proquest.com, diakses 23 Maret 2015)

Keesing, Roger M. (1974). "Theories of Culture". Annual Review of Anthropology. Vol. 3: 73-97, (Online), (https://www. annualreviews.org/, diakses 5 Maret 2018).

Latif, Yudi (2019). Memanjurkan Pancasila. Kompas, Jumat, 31 Mei 2019. 
Neuman, W. Lawrence. (2013). Metode Penelitian Sosial. Jakarta: PT Indeks.

Nucci, Larry P., \& Narvaez, Darcia. (2008). Handbook of Moral and Character Education. New York: Routledge, yang diterjemahkan oleh Imam Baehaqie dkk. (2014) dengan judul: Handbook Pendidikan Moral dan Karakter. Bandung: Nusa Media.

Noerhadi, Toeti Heraty. (2013). Aku dalam Budaya (Telaah Teori \& Metodologi Filsafat Budaya). Jakarta: Gramedia Pustaka Utama.

Olim, A., Suryatna, A., Hufad, A. 2007. Ilmu \& Aplikasi Pendidikan. Dalam Bagian 1 Teori Antropologi Pendidikan (Eds.), (hlm 253-283). Bandung: PT Imperial Bhakti Utama.

Rolston, H., Balée, W., Campbell, D., Durkee, V., Filemyr, A., Black, M., ... \& Young, E. (1996). Greening the college curriculum: A guide to environmental teaching in the liberal arts. Island Press.

Rosa, Milton and Daniel Clark Orey. (2014). A Theoretical Discussion to Reveal The Principles of Culturally Relevant Education in an Ethnomathematical Perspective. RIPEM Vol. 1 No. 1 2014.

Rachman, M. (2012). Konservasi nilai dan warisan budaya. Indonesian Journal of Conservation, 1(1).

Rosidi, A. (1984). Manusia Sunda; Sebuah esai tentang tokoh-tokoh sastra dan sejarah. Jakarta: Inti Idayu Press.

, (2002). Sejarah dan Budaya Politik. Bandung: Satya Historika.

, (2003). Sejarah Tatar

Sunda jilid I dan II. Bandung: Satya Historika.
Suryana, A. (2014, Oktober). Menuju ketahanan pangan Indonesia berkelanjutan 2025: tantangan dan penanganannya. Dalam Forum Penelitian Agro Ekonomi (Vol. 32, No. 2, pp. 123-135).

Sudaryat, Yayat. (2014). Wawasan Kesundaan. Bandung: Jurusan Pendidikan Bahasa Daerah, Fakultas Pendidikan Bahasa dan Sastra, Universitas Pendidikan Indonesia.

Suratno, T. (2010). Memaknai Etnopedagogi Sebagai Landasan Pendidikan Guru di Universitas Pendidikan Indonesia. In Proceedings of The 4th International Conference on Teacher Education.

Suryalaga, H.R. Hidayat. (2003). Kasundaan. Bandung: Wahana Raksa Sunda.

Suryalaga, H.R. Hidayat. (2010). Filsafat Sunda. Bandung: Yayasan Nur Hidayah.

Suseno, Frans Magnis. (...). Dasar-Dasar Etika

Timmerman, Benny Yohanes. (2018). Kajian Budaya: Diskursus dan Metodologi Riset. Bandung: Sunan Ambu Press.

Warnaen, S. (1986). Pandangan Hidup Orang Sunda; satu hasil studi awal. Makalah Depdikbud.

Warnaen, Suwarsih dkk. (1987). Pandangan Hidup Orang Sunda. Bandung: Sundanologi.

Wearing, S., \& Harris, M. (1999). An approach to training for indigenous ecotourism development. World Leisure \& Recreation, 41(2), 9-17.

Williams, Raymond. (1980). Problems in Materialism and Culture. London: Verso

Zuriah, Nurul. (2012). Kajian Etnopedagogi Pendidikan 
Kewarganegaraan Sebagai

Wahana Pendidikan Budaya dan

Karakter Bangsa di Perdosenan

Tinggi Muhamadiyah Kota
Malang. Jurnal Humanity, Vol.8

No.1 Tahun 2012. (www. umm.ac.id, diakses 20 Maret 2018 